\title{
CARACTERIZAÇÃo E IDENTIFICAÇÃO DAS CULTIVARES DE PESSEGUEIRO TROPI- CAL E DOURADÃO ATRAVÉS DE MARCADORES RAPD ${ }^{1}$
}

\author{
LÉO ZIMBACK ${ }^{2}$,WILSON BARBOSA ${ }^{3,6}$ EDSON SEIZO MORI ${ }^{4}$, RENATO FERRAZ DE ARRUDA VEIGA ${ }^{5}$
}

\begin{abstract}
RESUMO - Foi realizada a caracterização genética das cultivares de pêssego Tropical e Douradão pelo método RAPD, em comparação com 'Dourado1', 'Tutu', 'Maravilha', 'Rubro-sol', 'Flordaprince', 'Aurora-1' e 'Talismã' do Banco Ativo de Germoplasma de Frutas de Caroço do IAC, mantido no Núcleo de Agronomia de Capão Bonito, utilizando DNA extraído de folhas jovens. Foram obtidos 31 marcadores genéticos a partir dos primers altamente polimórficos OPAD10, OPAE04, OPAE07, OPAE09, OPAE11, OPAJ04 e OPAJ06, selecionados de 96 primers avaliados. Os marcadores RAPD utilizados indicaram eficientemente o grau de parentesco entre cultivares, exceto em cultivares originadas de polinização livre. Verificou-se que, mesmo entre as cultivares irmãs como 'Tutu' e 'Talismã', encontrou-se certa distância genética $(0,29)$, mostrando que por RAPD é possível caracterizarse germoplasma aparentado. 'Tropical' e 'Douradão' foram bem caracterizados em relação aos parentais e demais cultivares, com as distâncias genéticas variando de 0,26 a 0,89 .
\end{abstract}

Termos para indexação: Prunus persica (L.) Batsch, pêssego var. persica, marcador molecular, distância genética.

\section{CARACTERIZATION AND IDENTIFICATION OF TROPICAL AND DOURADÃO PEACH VARIETIES BY RAPD MARKERS}

\begin{abstract}
The genetic characterization for peach varieties Tropical and Douradão was realized by the RAPD method, also comparing with Dourado-1, Tutu, Maravilha, Rubro-sol, Flordaprince, Aurora-1 and Talismã varieties, from IAC "Frutas de Caroço" Germplasm Active Bank, maintained in Núcleo de Agronomia de Capão Bonito, using DNA extracted of young leaves, with the purpose of establishing efficient markers in the variety identification. Were obtained 31 markers from highly polimorphic primers OPAD10, OPAE04, OPAE07, OPAE09, OPAE11, OPAJ04 and OPAJ06, selected from 96 primers evaluated. The RAPD markers used, indicated the relationship degree among varieties in an efficient way; except in varieties of free polinization origin. Even among the varieties siblings as Tutu and Talismã had certain genetic distance $(0,29)$, showing that the RAPD is capable to characterize kindred materials. The Tropical and Douradão peaches varieties were well characterized in relation to the parents and others varieties, with genetic distances varying fron 0,26 to 0,89 .
\end{abstract}

Index terms: Prunus persica (L.) Batsch var. persica, peach, molecular marker, genetic distance.

A cultura do pêssego (Prunus persica (L.) Batsch var. persica) obteve grande impulso no Estado de São Paulo a partir da década de 60, com cultivares para inverno ameno do Planalto, tais como: 'Talismã', 'Maravilha', 'Joia', 'Ouromel' e 'Dourado', seguidas recentemente por outros tipos mais precoces e atraentes. As principais seleções de pêssego e nectarina adaptados a climas mais quentes foram obtidas no Instituto Agronômico (IAC), em seu programa de melhoramento genético iniciado em 1947 (Barbosa et al. 1997). Nos Estados Unidos, as cultivares de pêssego divergem geneticamente das cultivares Européias, em função de cruzamentos e seleção realizados (Arulsekar et al., 1986). Como a maioria dos paternais de pêssego do programa de melhoramento do Instituto Agronômico são de origem norte-americana, pode-se dizer que os genótipos brasileiros possuem base genética ampla. De acordo com Warburton e Bliss (1996), três dos 12 clusters obtidos com RAPD em pêssego, concentrou cultivares norte e latino americanas, alguns europeus e de ilhas do Pacífico, os demais nove apresentaram materiais da China, Paquistão, Rússia e Japão, sendo os chineses os materiais de maior diversidade genética. A cultivar brasileira Baronesa está no cluster II, onde se encontra o material norte americano com maior diversidade genética, se comparado com o cluster I.

O uso do RAPD tem sido utilizado com eficiência para identificação de cultivares de macieiras (Malus domestica Borkh.) (Koller et al., 1993), amoras vermelhas (Rubus idaeus L.) (Graham et al., 1994), ameixeiras (Prunus spp) (Ortiz et al., 1997) e roseiras (Rosa $\times$ hibrida) (Torres et al., 1993), sendo também um método rápido em relação ao RFLP e com maior número de marcadores em relação às isoenzimas. Pode ser muito útil na identificação de porta-enxertos, que são difíceis de identificar morfologicamente após a enxertia (Lu et al., 1996).
Este trabalho teve por objetivo a caracterização molecular através de RAPD e determinar a distância genética e o perfil dos marcadores de 'Tropical' e 'Douradão', juntamente com seus parentais e cultivares testemunhas, utilizadas como material para determinar distâncias genéticas.

Para extração de DNA, coletaram-se no Banco Ativo de Germoplasma de frutas de caroço do IAC, mantido no Núcleo de Agronomia de Capão Bonito, folhas jovens dos pessegueiros Douradão, Tropical, Dourado-1, Tutu, Aurora-1, Talismã e Flordaprince e da nectarineira Rubro-sol. Foram utilizadas $100 \mathrm{mg}$ de folhas frescas maceradas em $350 \mu \mathrm{l}$ de tampão de extração DNAzol da GIBCO, adicionando-se $300 \mu \mathrm{l}$ de clorofórmio, centrifugando-se após cinco minutos e precipitando-se o sobrenadante com etanol por cinco minutos. Após a centrifugação, o "pellet" foi tratado com RNAse a $10 \mathrm{mg} / \mathrm{ml}$ por 60 minutos para eliminar o RNA dos ácidos nucléicos e novamente centrifugado. O DNA do sobrenadante foi precipitado com $60 \mu \mathrm{l}$ de $\mathrm{NaCl}$ de concentração $5 \mathrm{M} \mathrm{e} 600$ $\mu \mathrm{l}$ de etanol 95\% e, após 30 minutos, centrifugado e o "pellet" dissolvido em $100 \mu \mathrm{l}$ de $0.1 \mathrm{TE}$.

Na amplificação utilizou-se 8 ng de DNA e $23 \mu 1$ do coquetel de amplificação com uma unidade de Taq DNA polimerase, denaturando o DNA a $94^{\circ} \mathrm{C}$ por dois minutos, seguido de 35 ciclos de $94^{\circ} \mathrm{C}$ por 1 minuto, $35^{\circ} \mathrm{C}$ por 1 minuto, $72^{\circ} \mathrm{C}$ por 1 minuto e 30 segundos, incubando a seguir com $72^{\circ} \mathrm{C}$ por 6 minutos. O produto amplificado foi colocado em gel de agarose a $1,5 \%$, submetido a eletroforese a $80 \mathrm{~V}$ por 3 horas, sendo revelado com brometo de etídio $0,25 \%$ por uma hora e fotografado sob luz UV com filme Polaroid e filtro laranja. Foram testados 48 primers e selecionados os 7 altamente polimórficos para o estudo, com 31 bandas polimórficas.

Os resultados foram analisados pelo programa NTSYS versão

\footnotetext{
(Trabalho 098/2002). Recebido: 15/07/2002. Aceito para publicação: 09/05/2003. Pesquisa integrante do subprojeto IAC: Conservação, caracterização e comportamento regional do germoplasma de frutíferas de clima temperado e subtropical.

${ }^{2}$ Eng. Agr. Dr., Pesquisador Científico (PqC), Centro Experimental de Campinas (CEC) do Instituto Agronômico (IAC), telefone (19)32415188, Caixa Postal 28, CEP 13001-970, Campinas, SP. E-mail: 1zimback@iac.br.

${ }^{3}$ Biólogo, M. Sc., PqC, CEC, IAC, telefone (19)32415188, E-mail: wbarbosa@iac.br.

${ }^{4}$ Eng. Florestal, Prof., Dr. da Faculdade de Ciências Agronômicas (FCA) da Universidade Estadual Paulista (UNESP), Botucatu, telefone (14)68027161, SP, Caixa Postal 237, CEP 18603-970, E-mail: esmori@fca.unesp.br.

${ }^{5}$ Eng. Agr. Dr., PqC, CEC, IAC, telefone (19)32415188, E-mail: veiga@barao.iac.br.

${ }^{6}$ Bolsista do CNPq.
} 
TABELA 1 - Marcadores RAPD utilizados para caracterizar 9 cultivares de pêssego (Prunus persica (L.) Batsch var. persica), indicando a presença de banda pelo uso do símbolo “+”.

\begin{tabular}{|c|c|c|c|c|c|c|c|c|c|}
\hline Cultivares & Douradão & Tropical & Dourado-1 & Maravilha & Tutu & Rubro-sol & Aurora-1 & Talismã & Flordaprince \\
\hline Marcadores & & & & & & & & & \\
\hline OPAD10-580 & & + & & & & + & & & \\
\hline OPAD10-800 & + & + & + & + & + & + & & + & + \\
\hline OPAD10-1000 & + & + & + & + & + & + & & + & \\
\hline OPAE04-380 & + & & + & + & + & & + & & + \\
\hline OPAE04-930 & + & + & + & & + & & & + & \\
\hline OPAE04-1300 & & + & + & + & & & & & \\
\hline OPAE04-1400 & + & + & & + & + & + & + & + & + \\
\hline OPAE07-620 & & + & & + & & + & & + & + \\
\hline OPAE07-720 & + & + & + & + & + & & & + & + \\
\hline OPAE07-800 & + & & & & & & & & \\
\hline OPAE09-480 & + & + & + & + & + & + & + & & \\
\hline OPAE09-880 & & + & + & + & & + & & + & \\
\hline OPAE09-1050 & & + & + & + & + & + & & + & + \\
\hline OPAE11 -450 & & & + & & & & + & + & + \\
\hline OPAE11 -550 & & & & & & & & + & \\
\hline OPAE11 -620 & & & & & & & + & & \\
\hline OPAE11 -650 & & & & & & & + & & \\
\hline OPAE11 -700 & & & & + & + & & + & + & + \\
\hline OPAE11-1050 & & + & + & + & + & & & + & \\
\hline OPAE11-1100 & + & + & + & + & + & & + & & \\
\hline OPAE11-1200 & & + & + & + & + & & & + & \\
\hline OPAE11 -1400 & & + & + & + & + & & & + & \\
\hline OPAJ04-400 & & + & & & & & & & \\
\hline OPAJ04-1200 & + & + & + & + & + & + & & + & + \\
\hline OPAJ04-1700 & + & & + & & + & + & + & + & \\
\hline OPAJ04-1900 & + & + & + & + & + & + & & + & + \\
\hline OPAJ06-580 & + & + & + & + & + & + & & + & + \\
\hline OPAJ06-730 & & + & & & + & & & + & \\
\hline OPAJ06-850 & + & & & & & & & & \\
\hline OPAJ06-1000 & + & & & & + & & + & + & + \\
\hline OPAJ06-1700 & + & + & + & + & + & + & & + & \\
\hline
\end{tabular}

1.70 (Rohlf e Slice, 1992), utilizando as distâncias genéticas de Jaccard e aplicando o dendrograma de similaridade genética pelo método do UPGMA.

Na Tabela 1 estão os marcadores RAPD utilizados para caracterizar as cultivares pesquisadas. No pêssego 'Tropical' houve confirmação da maioria das marcas das suas avós 'Tutu' e 'Rubro-sol', mas algumas delas podem ter sido adquiridas durante a polinização aberta da seleção IAC 371-2, seu parental feminino (Figura 1), ou numa recombinação genética naquela geração. O mesmo se observou em 'Douradão' com relação a 'Dourado-1' em frequiência mais alta. Os avós destas seleções, 'Maravilha' e 'Tutu', confirmaram os marcadores em 'Dourado-1', exceto em OPAE11-450

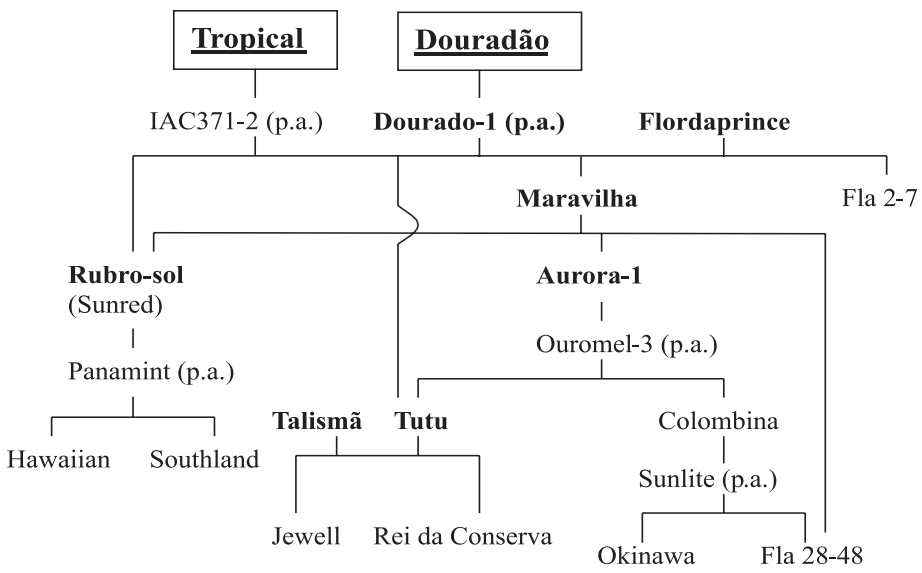

FIGURA 1 - Genealogia de 9 cultivares de pêssego (Prunus persica (L.) Batsch var. persica), do programa de melhoramento genético do Instituto Agronômico. p.a.: polinização aberta
Excetuando 'Talismã', que é irmã de 'Tutu', as demais: 'Flordaprince', 'Rubro-sol' e 'Aurora-1', possuem um perfil de marcadores claramente distintos, evidenciados na Figura 2, onde estão mais destacadas no dendrograma de similaridade, mostrando uma maior distância das demais. O mesmo ocorreu com 'Douradão', com grande probabilidade de 'Dourado-1' ter sido polinizado por um material geneticamente distante. Evidencia-se na Figura 2 a similaridade de 'Tropical', 'Maravilha', 'Dourado-1', 'Tutu' e 'Talismã', cuja análise de genealogia confirma alto grau de parentesco, citado por Lu et al. (1996), que também encontraram relação entre marcadores RAPD e genealogia de 18 cultivares de pêssego porta enxerto, sendo que, os desvios observados no presente trabalho, se devem às polinizações abertas, tal como detectado por Warburton e Bliss (1996). A cultivar Aurora-1, também tem parentesco com 'Tutu' e a seleção Fla 28-48, que faz parte da genealogia do 'Douradão', é o cultivar com as maiores distâncias do grupo, talvez em função de polinizações abertas com material geneticamente distanciado.

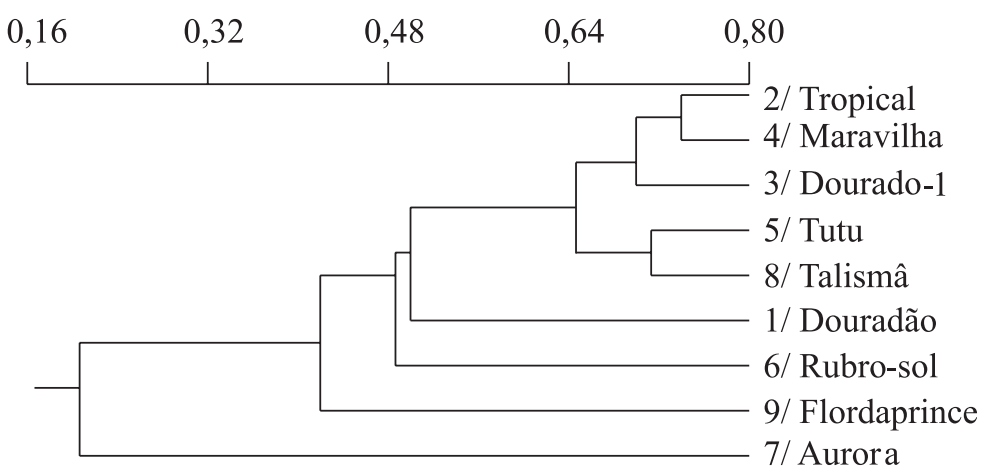

FIGURA 2 - Dendrograma de similaridade genética de Jaccard, entre os cultivares de pêssego (Prunus persica (L.) Batsch var. persica). 
TABELA 2 - Distâncias genéticas de Jaccard entre 9 cultivares de pêssego (Prunus persica (L.) Batsch var. persica), a partir de 31 marcadores RAPD polimórficos gerados por 7 primers.

\begin{tabular}{lccccccc}
\hline & Douradão & Tropical & Dourado-1 & Maravilha & Tutu & Rubro-sol & Aurora-1 \\
\hline Tropical & 0,58 & & & & & \\
Dourado-1 & 0,48 & 0,33 & & & & \\
Maravilha & 0,54 & 0,26 & 0,27 & & & \\
Tutu & 0,36 & 0,36 & 0,30 & 0,30 & & & \\
Rubro-sol & 0,55 & 0,45 & 0,54 & 0,48 & 0,56 & & \\
Aurora-1 & 0,70 & 0,89 & 0,79 & 0,79 & 0,70 & 0,85 & 0,81 \\
Talismã & 0,58 & 0,38 & 0,40 & 0,40 & 0,29 & 0,52 & 0,71 \\
Flordaprince & 0,60 & 0,68 & 0,65 & 0,52 & 0,55 & 0,61 & 0,50 \\
\hline
\end{tabular}

As menores distâncias observadas (Tabela 2) foram entre 'Maravilha' e 'Tropical' (0,26), 'Maravilha' e 'Dourado-1' (0,27), e também entre 'Tutu' e 'Talismã', que são irmãos $(0,29)$. Curiosamente, 'Tropical' não tem descendência de 'Maravilha', e sim de 'Rubro-sol', que por sua vez é parental de 'Maravilha'. Assim sendo, existe a possibilidade de 'Maravilha' ter participado da polinização aberta da seleção IAC371-2, mãe de 'Tropical', uma vez que 'Rubrosol' é geneticamente um pouco distante deste clone.

A análise de agrupamento não foi possível em função de um alto estresse e baixa correlação entre as distâncias reais e as calculadas. Neste trabalho se confirmou as observações de Ortiz et al. (1997), pela quais encontrou-se alto grau de polimorfismo no RAPD em 31 cultivares de ameixa e espécies relacionadas, a ponto de três primers serem suficientes para a identificação.

As conclusões deste trabalho são as seguintes:

- Os marcadores RAPD utilizados possibilitaram a indicação do grau de parentesco entre cultivares de pessegueiro;

- Mesmo entre as cultivares irmãs como ‘Tutu' e 'Talismã' houve certa distância genética $(0,29)$, mostrando que o método do RAPD pode ser usado para germoplasma aparentado;

- Os pêssegos 'Tropical' e 'Douradão' foram bem caracterizados em relação aos parentais e demais cultivares, o que permite utilizar a técnica para o registro das novas cultivares.

\section{REFERÊNCIASBIBLIOGRÁFICAS}

ARULSEKAR, S.; PARFITT, D.E.; KESTER, D.E. Comparison of isozyme variability in peach and almond cultivars. Journal of Heredity, Washington, v. 77, p. 272-274, 1986.
BARBOSA, W.; OJIMA, M.; CAMPO-DALL'ORTO, F. A.; RIGITANO, O.; MARTINS, F. P.; SANTOS, R. R.; CASTRO, J. L. Melhoramento do pessegueiro para regiões de clima subtropical-temperado: realizações do Instituto Agronômico no período de 1950 a 1990. Campinas: IAC, 1997. 22p. (Documentos IAC, 52).

GRAHAM, J.; McNICOL, R. J.; GERIG, K.; VANDEVEN, W. T. G. Identification of red raspberry cultivars and na assesment of their relatedness using fingerprints produced by random primers. Journal of Horticultural Science, London, v. 69, n. 1, p. 123-130, 1994.

KOLLER, B.; LEHMANN, A.; McDERMOTT, J. M.; GESSLER, D. Identification of apple cultivars using RAPD markers. Theoretical and Applied Genetics, Berlin, v.85, p. 901-904, 1993.

LU, Z.; REIGHARD, G.L.; BAIRD, W.V.; ABBOTT, A.G.; RAJAPAKSE, $\mathrm{S}$. Identification of peach rootstock cultivars by RAPD markers. HortScience, St. Joseph, USA, v. 31, n. 1, p. 127-129, 1996.

ORTIZ, A.; RENAULD, R.; CALZADA, I.; RITTER, E. Analysis of plum cultivars whith RAPD markers. Journal of Horticultural Science, London, v. 72, n. 1, p. 1-9, 1997.

ROHLF, F. J.; SLICE, D.E. NTSYS-pc Numerical Taxonomy and Multivariate Analysis System. New York: Exeter Publications, 1992.

TORRES, A. M.; MILLAN, T.; CUBERO, J. I. Identifying rose cultivars using random amplified polymorphic DNA markers. HortScience, St. Joseph, v. 28, p. 333-334, 1993.

WARBURTON, M. L.; BLISS, F. Genetic diversity in peach (Prunus persica $\mathrm{L}$. Batch) revealed by randomly amplified polimorphic DNA (RAPD) markers and compared to imbreeding coefficients. Journal of American Society of Horticultural Science, Alexandria, USA, v. 121,n. 6, p. 1012-1019, 1996. 